\title{
Clearance of apoptotic bodies, NETs, and biofilm DNA: implications for autoimmunity
}

\author{
Marko Radic* \\ ${ }^{*}$ Correspondence: mradic@uthsc.edu \\ Edited by: \\ Martin Herrmann, Universitätsklinikum Erlangen, Germany \\ Reviewed by: \\ Johan Van Der Vlag, Radboud University Nijmegen Medical Centre, Netherlands \\ Christine Schorn, University Hospital Erlangen-Nuremberg, Germany
}

Department of Microbiology, Immunology and Biochemistry, University of Tennessee Health Science Center, Memphis, TN, USA

Keywords: apoptosis, NETosis, clearance, autoimmunity, autoantibodies, lupus

\section{INTRODUCTION}

Apoptosis and NETosis, two important pathways of programed cell death, differ in their morphologic features and their effects on the immune system. In apoptosis, nuclear chromatin compacts as it is packaged into nuclear fragments and apoptotic blebs (1), and uptake of apoptotic cells by phagocytes generally suppresses the immune response (2). In NETosis, named after neutrophil extracellular traps (NETs), nuclear chromatin relaxes and forms a fibrous meshwork upon release from the cell (3). In general, NETosis is induced by infection, inflammation, or trauma and represents a mechanism of innate immune activation (4). Neutrophils, the most abundant type of white blood cells, migrate toward a stimulus in coordinated fashion, and NETs may synchronize such neutrophil swarms (5). Despite the structural and functional differences between apoptosis and NETosis, significant aspects of their clearance pathways likely overlap, as specific serum proteins participate in the recognition and uptake of remnants from either cell death pathway. In vivo, it is likely that both cell death pathways are concurrently present and that apoptotic bodies and NETs entangle (6). Yet, a third type of DNA may intertwine with DNA from apoptotic and NETotic cells, as certain bacteria and fungi release extracellular DNA that is used to construct biofilms (7). How apoptotic bodies, NETs, and biofilm DNA (Figure 1) are safely cleared is of great interest, because incomplete clearance leads to systemic inflammation and autoantibody production.

\section{SYSTEMIC AUTOIMMUNE DISEASES AND AUTOANTIBODIES TO NUCLEAR ANTIGENS}

Molecular structures associated with dying cells are targets of autoantibodies in autoimmune diseases such as systemic lupus (SLE) (8), antiphospholipid syndrome (APS) (9), as well as other musculoskeletal/rheumatoid disorders (10). The resulting autoreactivities are idiosyncratic for each condition and thus are useful for clinical diagnosis. However, the antigens recognized by the autoantibodies are also involved in pathogenesis, as they accumulate at the sites of tissue damage and contribute to immune complex deposition (11). Tissue damage may worsen in the absence of serum nucleases such as DNAse I (12). Furthermore, the interactions between dying cells and the adaptive immune system strengthen over time, as somatic mutations and antigen selection optimize antibodies for improved binding (13). In SLE, antibodies to nuclear or plasma membrane antigens arise in the course of disease $(14,15)$. These antibodies avidly bind to apoptotic cells (16). Classical studies recognized that apoptotic cells are far better substrates for autoantibody binding than viable cells (17). However, monoclonal antibodies from mouse lupus models that bind to apoptotic blebs (16) also tightly bind to NETs released in response to bacterial pathogens (18). Our laboratory showed that NETotic cells provide suitable targets for autoantibodies from diverse human autoimmune disorders (19). Whether apoptotic or NETotic cell death, or both, provide antigens that induce autoantibody production is

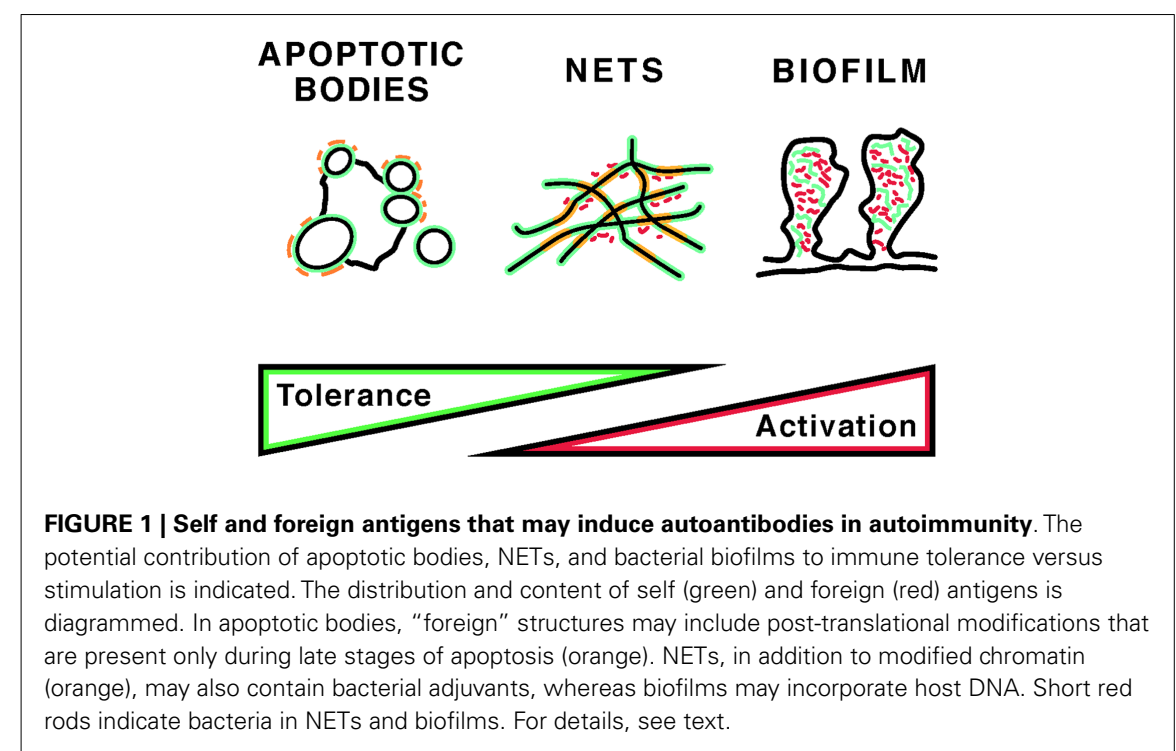


essential information for understanding the etiopathogenesis of autoimmune diseases (20).

\section{APOPTOTIC AND NETotic CELL DEATH}

Apoptosis is characterized by dramatic morphologic changes that are orchestrated by a family of specific proteases called caspases (21). The chromatin in the nucleus condenses tightly despite the fact that caspase-activated DNAse cleaves certain regions of genomic DNA to produce an oligonucleosome "ladder" (22). Curiously, the diameter (and thus the permeability) of nuclear pores transiently increases during this stage of apoptosis (23), and oligonucleosomes pass through the pores into the cytoplasm (16). The chromatin fragments associate with the outer nuclear envelope, the nucleus breaks up, and nuclear fragments migrate toward the cellular plasma membrane. These nuclear fragments form "blebs" at the cell surface, which are characteristic protrusions that give apoptotic cells their typical "grape cluster" appearance. Blebs display DNA, chromatin, and ribonucleoproteins at the cell surface $(16,24)$ such that these autoantigens become accessible to antibodies and pattern recognition receptors.

An alternative form of cell death was discovered by Brinkmann et al. (18). These authors reported that, upon exposure to bacteria, LPS, or PMA, neutrophils dissolve nuclear and cytoplasmic granule membranes, relax nuclear chromatin, associate the chromatin with granule components such as myeloperoxidase or elastase, and release the relaxed chromatin across the plasma membrane (4). The chromatin appears as disorganized fibers that spread widely to form an extracellular network. The authors named the fibers "NETs" because this chromatin could immobilize or "trap" bacteria. Mouse anti-chromatin antibodies were used to demonstrate that the NETs consisted of DNA and histones. These results immediately suggested that a tangle of bacteria and nuclear chromatin should be viewed as a "dangerous liaison" between lupus autoantigens and bacterial adjuvants that, by acting as a molecular complex, could trigger an adaptive immune response (25).

Follow-up studies revealed that NETs are not always an impediment to microbes. Proliferation assays identified certain species of bacteria that are resistant to any bactericidal effects of the released neutrophil chromatin (26), even though NETs organize bactericidal granule contents such as peroxidase and serine proteases (27), and even though histones also exhibit bactericidal activity (28). In fact, NET chromatin has found a novel use for certain bacteria that can incorporate NET chromatin into their extracellular matrix (29, 30). Such biofilms protect the microbes from physiological and pharmaceutical antibiotics and help to colonize various host tissues (7). DNA gives biofilms their structural integrity because nuclease treatment efficiently dissolves biofilms (31). The biofilms can also incorporate microbial DNA, as particular bacteria and fungi have mechanisms to release sections of genomic DNA for use in forming biofilms. Such DNA could be of particular significance in inducing anti-DNA responses because bacterial DNA has hypomethylated CpG motifs that directly stimulate toll-like receptors (32) and other DNA receptors (33) in B cells and other antigenpresenting cells.

\section{EVIDENCE FOR APOPTOSIS AND NETOSIS IN THE INDUCTION OF AUTOIMMUNITY}

Evidence supporting apoptotic cells as the source of autoantigens that induce and promote the development of autoimmunity derives from a close inspection of autoantibody specificities. The observation that lupus serum IgG bind to apoptotic cells (17) initiated an active area of research. Because apoptotic cells externalize phosphatidylserine at the cell surface, binding of serum factors or lupus antibodies to phosphatidylserine could interfere with clearance in a way that would alter recognition of apoptotic cells and potentially induce disease. This view is consistent with genetic defects in cell clearance that in many instances recreate the full set of lupus manifestations (8).

Completion of the apoptotic program without adequate clearance may lead to the exposure of highly modified autoantigens (34). Autoantibodies to apoptotic cells may be induced by unique antigenic structures that are produced by enzymatic reactions in apoptotic cells. Granzyme B activation in apoptosis was identified as one possible mechanism whereby apoptosis generates novel self antigens that stimulate autoantibody binding (35). Importantly, characteristic post-translational modifications (PTM) of histones are induced during apoptosis. These include the acetylation of lysine 12 in the H2B core histone, a PTM that was shown to enhance the binding of lupus autoantibodies (36). However, lysine 12 acetylation also occurs in NETosis, and tri-acetylated histone $\mathrm{H} 4$, a specific target of the KM-2 murine lupus autoantibody, is more abundant in NETs from SLE patients than in controls (37). Therefore, antibody reactivity against any single histone PTM may not unambiguously establish which biological process supplies nuclear antigens in autoimmunity (38).

The generation of apoptotic cells during development and under conditions of rapid cell turnover, such as exist physiologically in primary lymphoid organs, suggests that apoptotic lymphocytes provide a steady supply of tolerogenic autoantigens (39). The idea that apoptosis provides self antigens that maintain tolerance is supported by immune suppression following injection of apoptotic cells (40). Immune suppression by apoptotic cells can also be recreated in vitro (41) and can be converted to immune activation by opsonization of apoptotic cells with antibodies (42). On balance, NETosis is a more likely alternative source of autoantigens that stimulate autoreactive B cells. This follows directly from the observation that, in autoimmunity, autoantibodies arise to various known NET components $(43,44)$. These include the proteases cathepsin $\mathrm{G}$, proteinase 3 , and elastase, as well as granule peptides, including LL37 and other defensins that have bactericidal properties.

Detailed analysis revealed that neutrophils from autoimmune patients are more prone to NETosis than controls and that NETosis is associated with particular autoantigen modifications $(45,46)$. Such autoantigen PTM may arise through reactive oxygen species liberated in NETosis or through enzymes that are activated during the progression of NETosis. Amino acids such as tryptophan and tyrosine are modified by oxidation or reactions with hypochlorous acid and peroxynitrite (47). NETosis also activates peptidylarginine deiminases (PADs), enzymes that convert arginine residues in proteins to citrulline residues. Our laboratory was 
first to link deimination (also known as "citrullination") of nucleohistones to steps that are set in motion during NETosis (25). Importantly, we also showed that histone deimination is independent of caspase activity and that induction of apoptosis prevents PAD activation. Thus, deimination of histones clearly distinguishes NETosis from apoptosis.

In subsequent studies, we showed that citrullinated histones, including core and linker histones, are recognized in preference over non-modified histones by antibodies from patients with various autoimmune diseases, including SLE and Felty's syndrome, a more severe form of rheumatoid arthritis (10). In confirming our results, others have shown that autoantibodies to deiminated histones are remarkably useful in the diagnosis of rheumatoid arthritis (48). In earlier studies, it was reported that citrullinated proteins are frequently targets of IgG antibodies from patients with arthritis (49), and antibodies to citrullinated antigens have been a focus of a growing number of research studies $(50,51)$. These observations represent a solid link between NETosis and the induction of disease-specific autoantibodies.

\section{CLEARANCE MECHANISMS}

Clearance of apoptotic cells has been a focus of research for more than two decades (52), and a bewildering complexity of pathways has emerged (53). Different cell types participate in the uptake of apoptotic cells, the cells employ different combinations of receptors, and clearance may be enhanced or suppressed by various plasma proteins. Soluble plasma proteins that participate in apoptotic cell clearance include members of the pentraxin (54) and collectin families (55), the complement protein $\mathrm{Clq}$ (56), and milk fat globule epidermal growth factor 8 (MFG-E8) (57). An important "eat-me" signal is generated by the endoplasmic reticulum chaperone calreticulin. Apoptotic cells release calreticulin from the endoplasmic reticulum into the cytoplasm (58). The cytoplasmic calreticulin binds to phosphatidylserine in the inner leaflet of the plasma membrane from where it is externalized as the plasma membrane loses its asymmetry. At the cell surface, calreticulin combines with $\mathrm{C} 1 \mathrm{q}$ and binds CD91 on the surface of the macrophage, leading to the phagocytosis of the apoptotic cell
(59). Other receptors for uptake of apoptotic cells include SCARF1, a highly conserved receptor for $\mathrm{Clq}(60)$, and the integrin $\beta_{\mathrm{V}} \alpha_{5}$, a receptor for MFG-E8 (61). The importance of C1q, MFG-E8, and SCARF1 for tissue homeostasis is emphasized by the fact that mice deficient for any of these molecules show a reduced capacity for apoptotic cell clearance and exhibit a concomitant induction of autoantibodies (60, 62, 63). In SLE, altered levels of MFG-E8 in the serum and impaired $\mathrm{Clq}$ recognition of apoptotic cells correlate with the severity of disease manifestations $(64,65)$.

Additional receptors for the recognition and clearance of apoptotic cells are the Mer, Axl, and Tyro3 receptor tyrosine kinases (66). Mice deficient in any of these receptors manifest symptoms of autoimmune disease (67), and patients show altered serum levels of Mer family ligands GAS6 and protein S (68). Whereas Axl determines apoptotic cell clearance by dendritic cells (69), Mer is induced by C1q and serves to enhance apoptotic cell uptake by macrophage (70). It is important to note that several of these receptor-ligand systems are not specific for apoptotic cells but instead participate in the clearance of infectious microbes such as bacteria, fungi, and viruses (53). Possibly, some of these clearance pathways also serve to eliminate other cellular remnants.

Little is known about the clearance of NETotic cells, although a systematic analysis of the relevant mechanisms for NET clearance is urgently needed. Good starting points would be proteins and receptors that bind DNA or chromatin and that participate in the clearance of apoptotic cells. For example, several pentraxins (71) and collectins (55) bind to nucleic acids and chromatin, and calreticulin exhibits high affinity for chromatin and nucleosomes (72). It is likely that these proteins and receptors also bind NETs, although NETs are not efficiently recognized by the pentraxin C-reactive protein, or the complement protein $\mathrm{C} 3 \mathrm{~b}$ (73). In contrast, $\mathrm{C} 1 \mathrm{q}$ binds NETs and activates the complement cascade $(74,75)$. The search for additional factors that regulate NET clearance is timely because NETosis has been linked to atherosclerosis (76), small vessel vasculitis (77), deep vein thrombosis (78), and various autoimmune conditions (79). Conversely, autoimmune diseases show an aberrant persistence of NETs, and NET clearance is impaired in APS (80), SLE (81), and gout (82). A better knowledge of NET clearance is expected to lead to new treatments for autoimmune diseases, as inhibitors of PAD4 show promise in various animal models of autoimmune disorders (83-86).

\section{ACKNOWLEDGMENTS}

Thanks to Tim Higgins, Senior Scientific Illustrator for the design of (Figure 1). Research in the Radic lab is supported by the ORR Fund of Memphis, TN, USA.

\section{REFERENCES}

1. Kerr JF, Winterford CM, Harmon BV. Apoptosis. Its significance in cancer and cancer therapy. Cancer (1994) 73:2013-26.

2. Ravishankar B, Shinde R, Liu H, Chaudhary K, Bradley J, Lemos HP, et al. Marginal zone CD169+ macrophages coordinate apoptotic cell-driven cellular recruitment and tolerance. Proc Natl Acad Sci U S A (2014) 111:4215-20. doi:10.1073/pnas. 1320924111

3. Fuchs TA, Abed U, Goosmann C, Hurwitz R, Schulze I, Wahn V, et al. Novel cell death program leads to neutrophil extracellular traps. J Cell Biol (2007) 176:231-41. doi:10.1083/jcb.200606027

4. Brinkmann V, Zychlinsky A. Neutrophil extracellular traps: is immunity the second function of chromatin? J Cell Biol (2012) 198:773-83. doi:10.1083/ jcb. 201203170

5. Lammermann T, Afonso PV, Angermann BR, Wang JM, Kastenmuller W, Parent CA, et al. Neutrophil swarms require LTB4 and integrins at sites of cell death in vivo. Nature (2013) 498:371-5. doi:10. 1038/nature 12175

6. Manfredi AA, Covino C, Rovere-Querini P, Maugeri N. Instructive influences of phagocytic clearance of dying cells on neutrophil extracellular trap generation. Clin Exp Immunol (2014). doi:10.1111/cei.12320

7. Okshevsky M, Meyer RL. The role of extracellular DNA in the establishment, maintenance and perpetuation of bacterial biofilms. Crit Rev Microbiol (2013). doi:10.3109/1040841X.2013.841639

8. Munoz LE, Lauber K, Schiller M, Manfredi AA, Herrmann M. The role of defective clearance of apoptotic cells in systemic autoimmunity. Nat Rev Rheumatol (2010) 6:280-9. doi:10.1038/nrrheum. 2010.46

9. Andreoli L, Fredi M, Nalli C, Franceschini F, Meroni PL, Tincani A. Antiphospholipid antibodies mediate autoimmunity against dying cells. Autoimmunity (2013) 46:302-6. doi:10.3109/ 08916934.2013.783025

10. Dwivedi N, Radic M. Citrullination of autoantigens implicates NETosis in the induction of autoimmunity. Ann Rheum Dis (2014) 73:483-91. doi:10.1136/annrheumdis-2013-203844

11. van der Vlag J, Berden JH. Lupus nephritis: role of antinucleosome autoantibodies. Semin Nephrol (2011) 31:376-89. doi:10.1016/j.semnephrol.2011. 06.009 
12. Rekvig OP, Mortensen ES. Immunity and autoimmunity to dsDNA and chromatin - the role of immunogenic DNA-binding proteins and nuclease deficiencies. Autoimmunity (2012) 45:588-92. doi:10.3109/08916934.2012.719954

13. Shlomchik MJ, Aucoin AH, Pisetsky DS, Weigert MG. Structure and function of anti-DNA autoantibodies derived from a single autoimmune mouse. Proc Natl Acad Sci U S A (1987) 84: 9150-4.

14. Cocca BA, Cline AM, Radic MZ. Blebs and apoptotic bodies are B cell autoantigens. J Immunol (2002) 169:159-66. doi:10.4049/jimmunol.169.1. 159

15. Cocca BA, Seal SN, D’Agnillo P, Mueller YM, Katsikis PD, Rauch J, et al. Structural basis for autoantibody recognition of phosphatidylserine-beta 2 glycoprotein I and apoptotic cells. Proc Natl Acad Sci U S A (2001) 98:13826-31. doi:10.1073/pnas. 241510698

16. Radic M, Marion T, Monestier M. Nucleosomes are exposed at the cell surface in apoptosis. J Immunol (2004) 172:6692-700. doi:10.4049/jimmunol.172. 11.6692

17. Casciola-Rosen LA, Anhalt G, Rosen A. Autoantigens targeted in systemic lupus erythematosus are clustered in two populations of surface structures on apoptotic keratinocytes. J Exp Med (1994) 179:1317-30. doi:10.1084/jem.179.4.1317

18. Brinkmann V, Reichard U, Goosmann C, Fauler B, Uhlemann Y, Weiss DS, et al. Neutrophil extracellular traps kill bacteria. Science (2004) 303:1532-5. doi:10.1126/science.1092385

19. Dwivedi N, Upadhyay J, Neeli I, Khan S, Pattanaik D, Myers L, et al. Felty's syndrome autoantibodies bind to deiminated histones and neutrophil extracellular chromatin traps. Arthritis Rheum (2012) 64:982-92. doi:10.1002/art.33432

20. Bouts YM, Wolthuis DF, Dirkx MF, Pieterse E, Simons EM, van Boekel AM, et al. Apoptosis and NET formation in the pathogenesis of SLE. Autoimmunity (2012) 45:597-601. doi:10.3109/ 08916934.2012 .719953

21. Marino G, Niso-Santano M, Baehrecke EH, Kroemer G. Self-consumption: the interplay of autophagy and apoptosis. Nat Rev Mol Cell Biol (2014) 15:81-94. doi:10.1038/nrm3735

22. Iglesias-Guimarais V, Gil-Guinon E, SanchezOsuna M, Casanelles E, Garcia-Belinchon M, Comella JX, et al. Chromatin collapse during caspase-dependent apoptotic cell death requires DNA fragmentation factor, $\quad 40-\mathrm{kDa}$ subunit-/caspase-activated deoxyribonuclease-mediated 3'-OH single-strand DNA breaks. J Biol Chem (2013) 288:9200-15. doi:10.1074/jbc.M112.411371

23. Strasser C, Grote P, Schauble K, Ganz M, FerrandoMay E. Regulation of nuclear envelope permeability in cell death and survival. Nucleus (2012) 3:540-51. doi:10.4161/nucl.21982

24. Radic MZ, Shah K, Zhang W, Lu Q, Lemke G, Hilliard GM. Heterogeneous nuclear ribonucleoprotein P2 is an autoantibody target in mice deficient for Mer, Axl, and Tyro3 receptor tyrosine kinases. JImmunol (2006) 176:68-74. doi:10.4049/ jimmunol.176.1.68

25. Neeli I, Khan SN, Radic M. Histone deimination as a response to inflammatory stimuli in neutrophils. J Immunol (2008) 180:1895-902. doi: 10.4049/jimmunol.180.3.1895

26. Juneau RA, Pang B, Weimer KE, Armbruster CE, Swords WE. Nontypeable Haemophilus influenzae initiates formation of neutrophil extracellular traps. Infect Immun (2011) 79:431-8. doi:10.1128/ IAI.00660-10

27. Yoo DG, Winn M, Pang L, Moskowitz SM, Malech HL, Leto TL, et al. Release of cystic fibrosis airway inflammatory markers from Pseudomonas aeruginosa-stimulated human neutrophils involves NADPH oxidase-dependent extracellular DNA trap formation. J Immunol (2014) 192:4728-38. doi:10.4049/jimmunol.1301589

28. Hirsch JG. Bactericidal action of histone. JExp Med (1958) 108:925-44.

29. Malcolm KC, Nichols EM, Caceres SM, Kret JE, Martiniano SL, Sagel SD, et al. Mycobacterium abscessus induces a limited pattern of neutrophil activation that promotes pathogen survival. PLoS One (2013) 8:e57402. doi:10.1371/journal.pone. 0057402

30. van Gennip $M$, Christensen LD, Alhede $M$, Qvortrup K, Jensen PO, Hoiby N, et al. Interactions between polymorphonuclear leukocytes and Pseudomonas aeruginosa biofilms on silicone implants in vivo. Infect Immun (2012) 80:2601-7. doi:10.1128/IAI.06215-11

31. Whitchurch CB, Tolker-Nielsen T, Ragas PC, Mattick JS. Extracellular DNA required for bacterial biofilm formation. Science (2002) 295:1487. doi:10.1126/science.295.5559.1487

32. Green NM, Marshak-Rothstein A. Toll-like receptor driven B cell activation in the induction of systemic autoimmunity. Semin Immunol (2011) 23:106-12. doi:10.1016/j.smim.2011.01. 016

33. Paludan SR, Bowie AG. Immune sensing of DNA. Immunity (2013) 38:870-80. doi:10.1016/j. immuni.2013.05.004

34. Cline AM, Radic MZ. Apoptosis, subcellular particles, and autoimmunity. Clin Immunol (2004) 112:175-82. doi:10.1016/j.clim.2004.02.017

35. Casciola-Rosen L, Andrade F, Ulanet D, Wong WB, Rosen A. Cleavage by Granzyme B is strongly predictive of autoantigen status: implications for initiation of autoimmunity. J Exp Med (1999) 190:815-26. doi:10.1084/jem.190.6.815

36. van Bavel CC, Dieker J, Muller S, Briand JP, Monestier M, Berden $\mathrm{JH}$, et al. Apoptosis-associated acetylation on histone $\mathrm{H} 2 \mathrm{~B}$ is an epitope for lupus autoantibodies. Mol Immunol (2009) 47:511-6. doi:10.1016/j.molimm.2009.08.009

37. Pieterse E, Hofstra J, Berden J, Herrmann M, Dieker J, van der Vlag J. Acetylated histones contribute to the immunostimulatory potential of neutrophil extracellular traps in systemic lupus erythematosus. Clin Exp Immunol (2014). doi:10.1111/cei. 12359

38. Pieterse E, van der Vlag J. Breaking immunological tolerance in systemic lupus erythematosus. Front Immunol (2014) 5:164. doi:10.3389/fimmu.2014. 00164

39. Savill J, Fadok V. Corpse clearance defines the meaning of cell death. Nature (2000) 407:784-8. doi:10.1038/35037722

40. Ravichandran KS. Beginnings of a good apoptotic meal: the find-me and eat-me signaling pathways. Immunity (2011) 35:445-55. doi:10. 1016/j.immuni.2011.09.004

41. Voll RE, Herrmann M, Roth EA, Stach C, Kalden JR, Girkontaite I. Immunosuppressive effects of apoptotic cells. Nature (1997) 390:350-1.

42. Janko C, Franz S, Munoz LE, Siebig S, Winkler S, Schett G, et al. CRP/anti-CRP antibodies assembly on the surfaces of cell remnants switches their phagocytic clearance toward inflammation. Front Immunol (2011) 2:70. doi:10.3389/fimmu.2011. 00070

43. Kaplan MJ, Radic M. Neutrophil extracellular traps: double-edged swords of innate immunity. J Immunol (2012) 189:2689-95. doi:10.4049/ jimmunol.1201719

44. Radic M, Marion TN. Neutrophil extracellular chromatin traps connect innate immune response to autoimmunity. Semin Immunopathol (2013) 35:465-80. doi:10.1007/s00281-013-0376-6

45. Khandpur R, Carmona-Rivera C, VivekanandanGiri A, Gizinski A, Yalavarthi S, Knight JS, et al. NETs are a source of citrullinated autoantigens and stimulate inflammatory responses in rheumatoid arthritis. Sci Transl Med (2013) 5:178ra140. doi:10.1126/scitranslmed.3005580

46. Villanueva E, Yalavarthi S, Berthier CC, Hodgin JB, Khandpur R, Lin AM, et al. Netting neutrophils induce endothelial damage, infiltrate tissues, and expose immunostimulatory molecules in systemic lupus erythematosus. J Immunol (2011) 187:538-52. doi:10.4049/jimmunol.1100450

47. Heinecke JW. Mass spectrometric quantification of amino acid oxidation products in proteins: insights into pathways that promote LDL oxidation in the human artery wall. FASEB J (1999) 13:1113-20.

48. Pratesi F, Dioni I, Tommasi C, Alcaro MC, Paolini I, Barbetti F, et al. Antibodies from patients with rheumatoid arthritis target citrullinated histone 4 contained in neutrophils extracellular traps. Ann Rheum Dis (2014) 73:1414-22. doi:10.1136/ annrheumdis-2012-202765

49. Schellekens GA, de Jong BA, van den Hoogen FH, van de Putte LB, van Venrooij WJ. Citrulline is an essential constituent of antigenic determinants recognized by rheumatoid arthritis-specific autoantibodies. J Clin Invest (1998) 101:273-81. doi:10.1172/JCI1316

50. Amara K, Steen J, Murray F, Morbach H, Fernandez-Rodriguez BM, Joshua V, et al. Monoclonal IgG antibodies generated from joint-derived B cells of RA patients have a strong bias toward citrullinated autoantigen recognition. J Exp Med (2013) 210:445-55. doi:10.1084/jem.20121486

51. Haag S, Schneider N, Mason DE, Tuncel J, Andersson IE, Peters EC, et al. Identification of new citrulline-specific autoantibodies, which bind to human arthritic cartilage, by mass spectrometric analysis of citrullinated type ii collagen. Arthritis Rheumatol (2014) 66:1440-9. doi:10.1002/art. 38383

52. Platt N, da Silva RP, Gordon S. Recognizing death: the phagocytosis of apoptotic cells. Trends Cell Biol (1998) 8:365-72. doi:10.1016/S09628924(98)01329-4

53. Poon IK, Hulett MD, Parish CR. Molecular mechanisms of late apoptotic/necrotic cell clearance. Cell Death Differ (2010) 17:381-97. doi:10.1038/cdd. 2009.195 
54. Deban L, Bottazzi B, Garlanda C, de la Torre YM, Mantovani A. Pentraxins: multifunctional proteins at the interface of innate immunity and inflammation. Biofactors (2009) 35:138-45. doi:10.1002/ biof. 21

55. Palaniyar N, Nadesalingam J, Clark H, Shih MJ, Dodds AW, Reid KB. Nucleic acid is a novel ligand for innate, immune pattern recognition collectins surfactant proteins A and D and mannosebinding lectin. J Biol Chem (2004) 279:32728-36. doi:10.1074/jbc.M403763200

56. Liang YY, Arnold T, Michlmayr A, Rainprecht D, Perticevic B, Spittler A, et al. Serum-dependent processing of late apoptotic cells for enhanced efferocytosis. Cell Death Dis (2014) 5:e1264. doi:10. 1038/cddis.2014.210

57. Lauber K, Keppeler H, Munoz LE, Koppe U, Schroder K, Yamaguchi $\mathrm{H}$, et al. Milk fat globuleEGF factor 8 mediates the enhancement of apoptotic cell clearance by glucocorticoids. Cell Death Differ (2013) 20:1230-40. doi:10.1038/cdd. 2013.82

58. Tarr JM, Young PJ, Morse R, Shaw DJ, Haigh R, Petrov PG, et al. A mechanism of release of calreticulin from cells during apoptosis. J Mol Biol (2010) 401:799-812. doi:10.1016/j.jmb.2010.06.064

59. Ogden CA, deCathelineau A, Hoffmann PR, Bratton D, Ghebrehiwet B, Fadok VA, et al. Clq and mannose binding lectin engagement of cell surface calreticulin and CD91 initiates macropinocytosis and uptake of apoptotic cells. J Exp Med (2001) 194:781-95. doi:10.1084/jem.194.6.781

60. Ramirez-Ortiz ZG, Pendergraft WF III, Prasad A, Byrne MH, Iram T, Blanchette CJ, et al. The scavenger receptor SCARF1 mediates the clearance of apoptotic cells and prevents autoimmunity. Nat Immunol (2013) 14:917-26. doi:10.1038/ni.2670

61. Toda S, Hanayama R, Nagata S. Two-step engulfment of apoptotic cells. Mol Cell Biol (2012) 32:118-25. doi:10.1128/MCB.05993-11

62. Hanayama R, Tanaka M, Miyasaka K, Aozasa K, Koike M, Uchiyama Y, et al. Autoimmune disease and impaired uptake of apoptotic cells in MFGE8-deficient mice. Science (2004) 304:1147-50. doi:10.1126/science.1094359

63. Mitchell DA, Pickering MC, Warren J, FossatiJimack L, Cortes-Hernandez J, Cook HT, et al. Clq deficiency and autoimmunity: the effects of genetic background on disease expression. I Immunol (2002) 168:2538-43. doi:10.4049/jimmunol.168.5. 2538

64. Donnelly S, Roake W, Brown S, Young P, Naik H, Wordsworth $\mathrm{P}$, et al. Impaired recognition of apoptotic neutrophils by the $\mathrm{C} 1 \mathrm{q} /$ calreticulin and CD91 pathway in systemic lupus erythematosus. Arthritis Rheum (2006) 54:1543-56. doi:10.1002/art.21783

65. Yamamoto N, Yamaguchi H, Ohmura K, Yokoyama T, Yoshifuji H, Yukawa N, et al. Serum milk fat globule epidermal growth factor 8 elevation may subdivide systemic lupus erythematosus into two pathophysiologically distinct subsets. Lupus (2014) 23:386-94. doi:10.1177/0961203314523870

66. Lu Q, Lemke G. Homeostatic regulation of the immune system by receptor tyrosine kinases of the Tyro 3 family. Science (2001) 293:306-11. doi:10.1126/science. 1061663
67. Scott RS, McMahon EJ, Pop SM, Reap EA, Caricchio R, Cohen PL, et al. Phagocytosis and clearance of apoptotic cells is mediated by MER. Nature (2001) 411:207-11. doi:10.1038/ 35079659

68. Recarte-Pelz P, Tassies D, Espinosa G, Hurtado B, Sala N, Cervera R, et al. Vitamin K-dependent proteins GAS6 and protein S and TAM receptors in patients of systemic lupus erythematosus: correlation with common genetic variants and disease activity. Arthritis Res Ther (2013) 15:R41. doi:10.1186/ar4199

69. Subramanian M, Hayes CD, Thome JJ, Thorp E, Matsushima GK, Herz J, et al. An AXL/LRP1/RANBP9 complex mediates DC efferocytosis and antigen cross-presentation in vivo. J Clin Invest (2014) 124:1296-308. doi:10.1172/JCI72051

70. Galvan MD, Foreman DB, Zeng E, Tan JC, Bohlson SS. Complement component Clq regulates macrophage expression of Mer tyrosine kinase to promote clearance of apoptotic cells. J Immunol (2012) 188:3716-23. doi:10.4049/ jimmunol.1102920

71. Du Clos TW. Pentraxins: structure, function, and role in inflammation. ISRN Inflamm (2013) 2013:379040. doi:10.1155/2013/379040

72. Kobayashi S, Uchiyama S, Sone T, Noda M, Lin $\mathrm{L}$, Mizuno $\mathrm{H}$, et al. Calreticulin as a new histone binding protein in mitotic chromosomes. Cytogenet Genome Res (2006) 115:10-5. doi:10.1159/ 000094795

73. Schorn C, Janko C, Latzko M, Chaurio R, Schett G, Herrmann M. Monosodium urate crystals induce extracellular DNA traps in neutrophils, eosinophils, and basophils but not in mononuclear cells. Front Immunol (2012) 3:277. doi:10.3389/ fimmu.2012.00277

74. Farrera C, Fadeel B. Macrophage clearance of neutrophil extracellular traps is a silent process. J Immunol (2013) 191:2647-56. doi:10.4049/ jimmunol.1300436

75. Leffler J, Martin M, Gullstrand B, Tyden H, Lood C, Truedsson L, et al. Neutrophil extracellular traps that are not degraded in systemic lupus erythematosus activate complement exacerbating the disease. J Immunol (2012) 188:3522-31. doi:10.4049/ jimmunol.1102404

76. Doring Y, Manthey HD, Drechsler M, Lievens D, Megens RT, Soehnlein O, et al. Auto-antigenic protein-DNA complexes stimulate plasmacytoid dendritic cells to promote atherosclerosis. Circulation (2012) 125:1673-83. doi:10.1161/ CIRCULATIONAHA.111.046755

77. Kessenbrock K, Krumbholz M, Schonermarck U, Back W, Gross WL, Werb Z, et al. Netting neutrophils in autoimmune small-vessel vasculitis. Nat Med (2009) 15:623-5. doi:10.1038/nm.1959

78. Martinod K, Demers M, Fuchs TA, Wong SL, Brill A, Gallant M, et al. Neutrophil histone modification by peptidylarginine deiminase 4 is critical for deep vein thrombosis in mice. Proc Natl Acad Sci U S A (2013) 110:8674-9. doi:10.1073/pnas. 1301059110

79. Knight JS, Carmona-Rivera C, Kaplan MJ. Proteins derived from neutrophil extracellular traps may serve as self-antigens and mediate organ damage in autoimmune diseases. Front Immunol (2012) 3:380. doi:10.3389/fimmu.2012.00380

80. Leffler J, Stojanovich L, Shoenfeld Y, Bogdanovic G, Hesselstrand R, Blom AM. Degradation of neutrophil extracellular traps is decreased in patients with antiphospholipid syndrome. Clin Exp Rheumatol (2014) 32:66-70.

81. Hakkim A, Furnrohr BG, Amann K, Laube B, Abed UA, Brinkmann V, et al. Impairment of neutrophil extracellular trap degradation is associated with lupus nephritis. Proc Natl Acad Sci U S A (2010) 107:9813-8. doi:10.1073/pnas. 0909927107

82. Schauer C, Janko C, Munoz LE, Zhao Y, Kienhofer D, Frey B, et al. Aggregated neutrophil extracellular traps limit inflammation by degrading cytokines and chemokines. Nat Med (2014) 20:511-7. doi: 10.1038/nm.3547

83. Chumanevich AA, Causey CP, Knuckley BA, Jones JE, Poudyal D, Chumanevich AP, et al. Suppression of colitis in mice by $\mathrm{Cl}$-amidine: a novel peptidylarginine deiminase inhibitor. Am J Physiol Gastrointest Liver Physiol (2011) 300:G929-38. doi:10.1152/ajpgi.00435.2010

84. Knight JS, Zhao W, Luo W, Subramanian V, O’Dell AA, Yalavarthi S, et al. Peptidylarginine deiminase inhibition is immunomodulatory and vasculoprotective in murine lupus. J Clin Invest (2013) 123:2981-93. doi:10.1172/JCI67390

85. Wei L, Wasilewski E, Chakka SK, Bello AM, Moscarello MA, Kotra LP. Novel inhibitors of protein arginine deiminase with potential activity in multiple sclerosis animal model. J Med Chem (2013) 56:1715-22. doi:10.1021/ jim $301755 q$

86. Willis VC, Gizinski AM, Banda NK, Causey CP, Knuckley B, Cordova KN, et al. N-alpha-benzoylN5-(2-chloro-1-iminoethyl)-L-ornithine amide, a protein arginine deiminase inhibitor, reduces the severity of murine collagen-induced arthritis. J Immunol (2011) 186:4396-404. doi:10.4049/ jimmunol.1001620

Conflict of Interest Statement: The author declares that the research was conducted in the absence of any commercial or financial relationships that could be construed as a potential conflict of interest.

Received: 20 June 2014; accepted: 15 July 2014; published online: 30 July 2014.

Citation: Radic M (2014) Clearance of apoptotic bodies, NETs, and biofilm DNA: implications for autoimmunity. Front. Immunol. 5:365. doi: 10.3389/fimmu.2014.00365 This article was submitted to Molecular Innate Immunity, a section of the journal Frontiers in Immunology. Copyright (c) 2014 Radic. This is an open-access article distributed under the terms of the Creative Commons Attribution License (CC BY). The use, distribution or reproduction in other forums is permitted, provided the original author(s) or licensor are credited and that the original publication in this journal is cited, in accordance with accepted academic practice. No use, distribution or reproduction is permitted which does not comply with these terms. 